\title{
Editorial
}

\section{Brand valuation - introduction to the Special Issue}

'... when Rupert Murdoch bought The Times of London, the first thing that he did was to enter on its balance sheet a good-will item of as much as $£ 50 \mathrm{~m}-$ When his solicitors said he couldn't do that, Murdoch asked why not? ... Why do you think I paid $£ 27 \mathrm{~m}$ for it? ... For the printing plant? ... I'm shutting that down. - For its staff? - Talent is for hire ... I bought it for its name.- I own The Times of London.'

I begin with the above quotation because in its starkness it tells me why the issue of brand valuation refuses to go away. A previous contributor to this Journal wished it would all go away.

'Brands need to be managed with a view to their long-term market position, respecting their contract and relationship with the consumer. There are many different kinds of performance indicator which will monitor these factors. A value can also be put on brands as assets when necessary, and they can be bought and sold. But all this can be done without assuming the existence of anything called brand equity. In fact the whole area might be easier to understand if people stopped using those words altogether.'

But here we go again, why? Certainly not because Murdoch says so. And the cynical Guardian reader in me says that The Times is a fine example of a brand whose value, over time, has been squandered. No, I am interested in brand valuation for a number of rea- sons. Financial, economic, organisational, strategic. I want to pursue the brand valuation debate because thus far it has been too narrow in scope.

Hugh Davidson states in his new book:

'Company reports in the UK and the USA fail to give a true and fair picture of a company's position, because there is no requirement to disclose intangible investments like advertising, $\mathrm{R} \& \mathrm{D}$, training, innovation and customer relationships. It is ridiculous that companies can cut spending on such intangibles, and then report artificially inflated short-term profits, while stripping the long-term value of their customer equity. Ironically, the purpose of such exercises is usually to increase a company's stock market valuation. 3

That certainly is one good reason for not dropping the brand value/brand equity debate. (I use brand value and brand equity as synonyms.) Another relates to the organisational and strategic dimensions. Another quote:

'Unfortunately many organisations espouse strategies about customer relationships, core competencies, and organisational capabilities while motivating and measuring performance only with financial measures ... in the short-term, the financial model reports ... spending cutbacks as increases in reported income, even when the reductions have cannibalised a company's stock of assets, and it capabilities for creating future economic value." 
I have put together a set of papers that explores all of the issues that I think are implicit in the above quotations and that will continue to inform the debate about brand valuation.

In the first paper, Egan sets up a comprehensive framework for the debate. 'Chasing the Holy Grail: A critical appraisal of the brand and the brand valuation debate' identifies a number of critical issues. He reminds us of the danger of dwelling solely on the economic/financial dimension. He states that brand management is as much a behavioural process as an economic construct. That view informs his whole approach to brand valuation. For example, any brand valuation methodology that ignores competitive dynamics is myopic, and we still do not have adequate models of competitiveness. That is why it is easier to argue for brand valuation in respect of mature industry brands. The problems arise in dynamic expanding markets. Egan provocatively asks how would one place a value on Netscape at the present time. He argues that the brand valuation debates is too narrow in scope, and that the debate has tended to ignore the fundamental levels of both economic and financial theory. His comments on acquisition cost valuation and the bid premium problem are well taken. The value of his contribution is, however, to put the brand valuation debate into its wider context. Time must be factored into the debate. Much of the valuation debate is built on securing a snapshot of the value of the brand at a moment in time. But brand management is about managing and enhancing value over time. That is why brand valuation is not just an economics issue, or a financial issue; it is about a process, a behavioural construct that may or may not harbour attempts to quantify value. That is why the debate continues.

In the second paper, 'Brand value: The future', Lisa Wood addresses brand equity and its role in financial reporting, management accounting and brand management. Importantly, she cannot be accused of a narrow focus, because she is really interested in brand management - over time, and indeed argues for brand management over functions as well. She raises an important issue early in her paper. Brand equity is seen by the accounting profession as part of their agenda (both the UK Accounting Standards Board and the International Accounting Standards Committee have spoken) with the result that brand equity is currently defined by custom and practice in the accounting profession. The marketing profession has a vital and vested interest in both the custom and the practice. Wood explores the relationship between the capitalisation of brands and brand management. She reports on empirical research done with agents of power in the food industry. A Delphi survey reveals that, by 2004, the food industry expects that Return on Capital Employed will be the standard measure by which brand managers are judged, that brand value will rate as part of the measurement of capital employed, that brand capitalisation in the balance sheet will be widely employed, and that brand management will be a cross-functional responsibility - and there is more!

Shân Kennedy was formerly the project director for the Accounting Standards Board when they took on board the problem of purchased brand valuation in financial reporting. Who better to comment on the standard, FRS 10, which was published in December 1997? Shân is now a Senior Executive of Ernst \& Young. I have not decided if this is gamekeeperess turned poacher or ... what. What is clear is that the language of FRS 10 makes few concessions to a marketer's understanding.

Lest we should for a moment be tempted to think that the Accounting Standards Board is in the business of issuing tablets of stone, David Oldroyd, in his exploration of the question of which vested interests are being served by FRS 10, is happy to take on ASB, the major auditing 
firms, the professional brand valuers (no names, no pack drill), and the vested interests of managers. 'Formulating an accounting standard for brands in the "market for excuses", is his appropriately provocative title.

Since most of the readers of this Journal earn an honest living at what used to be called the coal face, and which we post modern marketers simply call virtual reality, then we must offer some counterpoint to the philosophical debate that has preceded. In 'Combining economic and image analysis for breakthrough brand management', Almquist, Turvill and Roberts (all earn their living in virtual reality, aka American consultancy), look at the tools of economic analysis and brand imaging and find both the tools limiting. They have some strategic insights in mind, encapsulated in their integrated brand performance model. They advocate an integrated approach to brand equity, which should please Egan.

Egan reminded us that the brand valuation debate must encompass not just the economic/financial variables, but also the organisational/behavioural variables.

In 'Brand valuation: The times are a changing' by Ward and Perrier, evidence is provided regarding brand performance over a 20-year period, and strongly advocates a brand-centric approach. Virgin and $\mathrm{Mi}-$ crosoft are cited as examples of such an approach. They also comment on the need for a professional discipline of brand valuation.

Chris Macrae, who has now chosen to pursue virtual reality in America, argues in 'Valuing the future of the brand learning organisation', that marketers must be proactive in the debate and, by using eight mini-case studies, he demonstrates how the behavioural dynamic can, when effectively man- aged, transform brand value. Macrae is a brand value evangelist in the world of hyper-reality. 'Get netted' is a term he takes seriously. You are invited, dear reader, to participate in the dialogue.

We were unable to publish all the 'Special Issue' papers within this one issue, so we will be publishing further papers appertaining to brand valuation in the following two issues of this Volume. My friend Hugh Davidson, whose recently published 'Even More Offensive Marketing' is even more challenging than his first book (it will be reviewed in the next issue of this Journal) will, in one of these later issues, bring us all back to the coal face with his own personal reactions to the product mix on offer from these papers.

Since we are all netted, I am, as ever, more than happy to invite feedback from our readers.michaelt@market.strath.ac.uk will reach me faster than the speed of light.

\section{Michael Thomas Guest Editor}

\section{REFERENCES}

(1) Navasky, V. (1998) 'Saving the Nation', Atlantic Monthly, January, p. 82.

(2) Feldwick, P. (1996) 'Do we really need Brand Equity?', The Journal of Brand Management, Volume 4, Number 1, pp. 9-28.

(3) Davidson, H. (1997) 'Even More Offensive Marketing', Penguin Books, London, pp. 61-2.

(4) Kaplan, R. and Norton, D. (1996) 'The Balanced Scorecard', Harvard Business School Press, Cambridge, Mass. 